Illinois State University

ISU ReD: Research and eData

Theses and Dissertations

$10-13-2014$

\title{
The relationship between environmental factors and cyanobacteria population in Lake Bloomington and Evergreen Lake in McLean County, Illinois
}

Matthew Douglas Meyers

Illinois State University, mdmeyer@ilstu.edu

Follow this and additional works at: https://ir.library.illinoisstate.edu/etd

Part of the Geology Commons

\section{Recommended Citation}

Meyers, Matthew Douglas, "The relationship between environmental factors and cyanobacteria population in Lake Bloomington and Evergreen Lake in McLean County, Illinois" (2014). Theses and Dissertations. 275.

https://ir.library.illinoisstate.edu/etd/275

This Thesis is brought to you for free and open access by ISU ReD: Research and eData. It has been accepted for inclusion in Theses and Dissertations by an authorized administrator of ISU ReD: Research and eData. For more information, please contact ISUReD@ilstu.edu. 


\title{
THE RELATIONSHIP BETWEEN ENVIRONMENTAL FACTORS AND CYANOBACTERIA POPULATION IN LAKE BLOOMINGTON
} AND EVERGREEN LAKE IN MCLEAN COUNTY, ILLINOIS

\author{
Matthew D. Meyers
}

44 Pages

December 2014

This thesis investigates cyanobacteria on two lakes in McLean County, Illinois from the months of August to October.

Cyanobacteria are prokaryotes that may be unicellular, colonial or filamentous in form. These cells can be toxic or non-toxic. The factors that control the reproduction of cyanobacteria are the temperature and nutrients, nitrogen and phosphorus. These microorganisms are located in marine and freshwater settings worldwide. The site of this study was on two man-made lakes which are Lake Bloomington and Lake Evergreen. Sampling and collection of data were done on two lakes to explore the cyanobacteria density.

The data was collected by using an YSI Exo Sonde 1 to profile the water column for two main reasons which are chlorophyll a and phycocyanin. The other sensors on the probe also collected data for temperature, depth, conductivity, and dissolved oxygen. Samples were taken to run on FlowCam and Flow Injection Analysis. Results showed that cyanobacteria increased with the rise of water temperature and a higher concentration 
of nitrogen and phosphorus in the water. Overall, if water temperatures are warmer the colder, the lakes will have a higher abundance of cyanobacteria. Same with a low to N: P ratio, the cyanobacteria will be higher in the lakes.

The majority of the BGA-PC was found at 25-27 degrees Celsius in the water. There was found to be a higher concentration at the top and middle of the water column where the water temperature was warmer than at the bottom of the lake. Having a low N: P (Nitrogen and Phosphorus) in the water, showed a high concentration of cyanobacteria in Lake Bloomington and Evergreen Lake 
THE RELATIONSHIP BETWEEN ENVIRONMENTAL FACTORS AND CYANOBACTERIA POPULATION IN LAKE BLOOMINGTON AND EVERGREEN LAKE IN MCLEAN COUNTY, ILLINOIS

MATTHEW D. MEYERS

A Thesis Submitted in Partial Fulfillment of the Requirements for the Degree of

MASTER OF SCIENCE

Department of Geography-Geology

ILLINOIS STATE UNIVERSITY 
(C) 2014 Matthew D. Meyers 
THE RELATIONSHIP BETWEEN ENVIRONMENTAL FACTORS AND CYANOBACTERIA POPULATION IN LAKE BLOOMINGTON AND EVERGREEN LAKE IN MCLEAN COUNTY, ILLINOIS

MATTHEW D. MEYERS

COMMITTEE MEMBERS:

Catherine O’Reilly, Chair

Lisa Tranel

Bill Perry

Martha Cook 


\section{ACKNOWLEDGMENTS}

I would like to thank my committee, Drs. Catherine O'Reilly, Lisa Tranel, Bill Perry, and Martha Cook for their guidance, support and time during the course of my thesis project. I would like to thank the City of Bloomington who funded my thesis project. I would also like to thank Rick Twait and Jill Mayes from the City of Bloomington for their support and guidance using the FlowCam. I would like to thank my field partners Crystal Williams, Kristen Theesfeld, Nick Green, Even Meinzer for their assistance. I would also like to thank Brian Grebliunas for his support transporting the ISU boat to Evergreen Lake. To finish, I thank all my friends and family for their support and encouragement throughout my time at Illinois State University.

M. D. M. 


\section{CONTENTS}

\section{Page}

ACKNOWLEDGMENTS

CONTENTS

TABLES

FIGURES

\section{CHAPTER}

I. INTRODUCTION 1

Literature Review

Objective $\quad 5$

Hypothesis $\quad 6$

$\begin{array}{ll}\text { Study Site } & 7\end{array}$

$\begin{array}{ll}\text { II. METHODS } & 10\end{array}$

$\begin{array}{ll}\text { Field Procedure } & 10\end{array}$

YSI Exo Sonde Probe 11

$\begin{array}{ll}\text { Secchi Disk } & 12\end{array}$

Grab Sampler and Filtering $\quad 13$

Flow Injection Analysis $\quad 13$

$\begin{array}{ll}\text { FlowCam } & 14\end{array}$

$\begin{array}{ll}\text { II. RESULTS } & 18\end{array}$

Overview 18

Relationships between BGA -PC \& Temperature 19

Differences among BGA- PC \& Sites 21

Differences among BGA-PC \& T/M/B 23

Differences in Turbidity for T/M/B 25

Relationships between BGA- PC \& Log N:P ratio 27 
FlowCam Results

Depths \& Sites

Top Three Common Phytoplankton Groups FlowCam (5 microns)

IV. DISCUSSION

Influence of Water Temperature \& Depth on BGA-PC

Spatial Patterns in Nutrients \& BGA-PC

Phytoplankton Counts 


\section{TABLES}

Table

Page

1. WHO Recreational Water Guidelines for Human Health Risk (Modified from WHO 2003).

2. Watershed Features of Lake Bloomington and Evergreen Lake, McLean County, IL (Lake Bloomington \& Evergreen Lake Watershed Management Plan, 2008).

3. Samples Sites for Near Shore and Off Shore in Lake Bloomington (LB) and Lake Evergreen (LE), GPS Coordinates and the Average Depth of Each Site.

4. Images from the FlowCam for Lake Bloomington and Lake Evergreen. Images Show Top Three Phytoplankton Groups with the Remaining Common Phytoplankton.

5. The Mean and Standard Error for Blue Green Algae Phycocyanin, Chlorophyll a, Dissolved Oxygen, Temperature, and Turbidity for Lake Bloomington's and Evergreen Lake's Top, Middle, and Bottom. 


\section{FIGURES}

Figure $\quad$ Page

1. Lake Bloomington and Evergreen Lake (Sites 1-4 Marked as Dots) 7

2. Lake Bloomington and Evergreen Lake Watershed Land Use (\%) (Land Bloomington \& Evergreen Lake Watershed Management Plan, 2008)

3. The Relationship between Blue Green Algae - Phycocyanin Concentrations and Water Temperature for Lake Bloomington (a) and Evergreen Lake (b). The Figure Represents Data from Four Sites on Each Lake Collected in August through October for Every other Week. The First Week in October Data was not Collected Due to too not Working Properly.

4. The Differences among Blue Green Algae - Phycocyanin Concentrations at Sampling Sites for Lake Evergreen (a) and Lake Bloomington (b). The Figure Represents Data from Four Sites on Each Lake. Error Bars Represent Standard Error. Letters Represent Results from Tukey HSD. Similar Letters are not Significant having a $\mathrm{P}<0.05$.

5. The Differences among Blue Green Algae - Phycocyanin Concentrations for the Top, Middle, Bottom of the Water Column for Lake Bloomington (a) and Evergreen Lake (b). The Figure Represents Data from Four Sites on Each Lake. Error Bars Represent Standard Error. Letters Represent Results from Tukey HSD. Similar Letters are not Significant having a P $<0.05$.

6. The Differences among Turbidity in the Top, Middle, Bottom of the Water Column for Lake Bloomington (a) and Evergreen Lake (b). The Figure Represents Data from Four Sites on Each Lake. Error Bars Represent Standard Error. Letters Represent Results from Tukey HSD. Similar Letters are not Significant having a $\mathrm{P}<0.05$. 
7. The Relationship between Blue Green Algae - Phycocyanin Concentrations and Log N: P Ratio for Lake Bloomington (a) and Evergreen Lake (b). The Figure Represents Data from Four Sites on Each.

8. The Total Count at 25 microns for Each Site for Lake Bloomington (a) and Evergreen Lake (b). This Figure Represents Data for All Five Sampling Days Starting in August and Ending in October.

9. The Relationship between Total Water Depths at of Each Site and the Total Count of Images that were Taken on the FlowCam for Lake Bloomington and Evergreen Lake. The Data Represents Averages for All Five Sampling Days Starting in August and Ending in October.

10. The Two Graphs Represents the Total Count 25Microns for the Top 3 Groups between All Five Sampling Days for Lake Bloomington (a) and Evergreen Lake (b) and (c). 


\section{CHAPTER I}

\section{INTRODUCTION}

\section{Literature Review}

What are Cyanobacteria?

Cyanobacteria have been harmful to humans and animals worldwide for the past decades (Rolland, 2013). Before 1978, there were only about 50 publications documenting the human health effects of cyanobacteria, but from 2008 - 2012 there have been approximately 2,400 publications documenting the adverse effect of cyanobacteria blooms (Cheung et al., 2013). The World Health Organization (WHO) has documented outbreaks associated with recreational water, drinking water, and water used for hemodialysis. In 1988 in Brazil, approximately 2,000 people became ill due to drinking water contamination with a cyanobacteria bloom and 88 died (Teixera et al., 1993). Again in 1996, contaminated drinking water in Brazil killed 52 and hospitalized 64 (Carmichael et al., 2001). Although these are only two cases I have mentioned, there are hundreds of cyanobacteria cases globally affecting humans (Carmichael et al., 2001).

The name cyanobacteria came from the blue-green color of the bacteria, which are also known as blue-green bacteria and blue-green algae (BGA). (Packer \& Glazer 1988). The two pigments in cyanobacteria are chlorophyll a and phycocyanin (BGA-PC). These organisms are considered phytoplankton, which include microscopically small 
photosynthetic protists (algae) and small plants. Phytoplankton is separated into six groups by their size starting at less than 0.2 micrometers, femtoplankton, up to and the largest diameter greater than 20,000 micrometers, macroplankton. Femtoplankton consists of very small viruses and bacteria and macroplankton are small floating plants such as duckweed. Cyanobacteria have a diameter size range from 0.5-1 to 40 micrometers putting them in three groups, which are picoplankton $(0.2-2 \mu \mathrm{m})$, nanoplankton $(2-30 \mu \mathrm{m})$ and microplankton $(30-200 \mu \mathrm{m})($ Packer \& Glazer 1988). The size may be an important when looking at whether cyanobacteria are toxic or non- toxic.

Cyanobacteria may produce toxic compounds that can affect both aquatic and terrestrial organisms and causing medical consequences for humans. These toxic compounds are classified into three main groups: hepatotoxins, neurotoxins and dermatoxins (Carmichael 1992). Hepatotoxins affect the liver, neurotoxins affect the nervous system and dermatoxins affect the skin of a human or animal. The use of rats, guinea pigs, mice, pigs and rabbits have been laboratory studies involving hepatotoxins (Carmichael 1992). The effects of hepatotoxin on these animals include anorexia, pallor of mucous membranes, vomiting, weakness, diarrhea, and cold extremities (Carmichael 1992). The hepatotoxins known as microcystins, in particular, have been shown to have effects on humans and are produced by diverse cyanobacteria, including Anabaena, Aphanocapsa, Hapalosphon, Microcystis, Nostoc, Planktothrix (Oscillatoria). Of these taxa, Microcystis typically comprises $80 \%$ of cyanobacteria blooms (Sedmak et al., 1994) Sedmark and Kosi, 1997). A key indicator of a toxic bloom occurring is a unique taste and smell that cyanobacteria give off. Microcystins in drinking water supplies can have 
short -term effects such as gastrointestinal, liver inflammation, and hemorrhage and liver failure and also long- term effect such as tumor formation, liver failure and death (Cheung et al. 2013). Humans could encounter toxic cyanobacteria through ingestion, inhalation, and dermal contact. Drinking water is not the only concern, as recreational use of waters where algal blooms occur is also a concern (Backer et al. 2009). The WHO has developed three risk levels of contact with water in which algal blooms are occurring. According to the World Health Organization (WHO) Safe Guidelines there are three levels of human health effects concerning the recreational water containing cyanotoxin cells (Table 1). There are different environmental factors contributing to an increase of cyanobacteria concentration.

Table 1: WHO Recreational Water Guidelines for Human Health Risk (Modified from WHO 2003).

\begin{tabular}{|l|l|l|}
\hline $\begin{array}{l}\text { Probability of adverse } \\
\text { health effects }\end{array}$ & Cell concentration (per ml) & $\begin{array}{l}\text { Chlorophyll }- \text { a } \\
\text { Concentration (ug/L) }\end{array}$ \\
\hline Relatively low & $<20,000$ cells & $<10$ \\
\hline Moderate & $20,000-100,000$ cells & $10-50$ \\
\hline High & $>100,000$ cells (visible & Visible scum \\
& scum) & \\
\hline
\end{tabular}

In lakes, cyanobacteria reproduction and growth blooms are triggered by a combination of three primary factors: sunlight, warm water temperature, and excess nutrients (Ghadouni et al., 2003). Once cyanobacteria have reproduced, growth will be triggered by nutrients such as nitrogen and phosphorus. Eutrophic conditions lead to 
dense blooms of blue- green algae that can exclude or impact other planktonic organisms in freshwater systems.

Many studies described that cyanobacteria in the water column grow rapidly during the spring then become highly populated during the warmer months of summer (Cheung et al., 2012). Cyanobacteria are not likely to reproduce during the winter. Instead, they die or hibernate at the bottom of the water column (Xu et al., 2010). Cyanobacteria conditions are fitting for blooms when the temperature is greater than 20 degrees Celsius (Cheung et al., 2012). Shallow waters having a higher temperature can create a higher concentration of toxic cyanobacteria such as Microcystis aeruginosa (Ghadouni et al., 2003).

Higher concentrations of the toxin microcystin are more likely to occur in water with a low N:P ratio, rather than in water with a high N:P ratio (Orihel et al., 2012). In addition to Orihel et al. (2012), there have been others studies indicating that high phosphorus loads increase the chance of a cyanobacteria bloom (Lathrop et al., 1998). The concentration of toxin was high when the N:P ratio in Canadian fresh waters was between 0 and 40 (Orihel et al., 2012). High microcystin concentration was less likely to occur when the N:P ratio was between 100 and 120 .

Few studies have looked at spatial variability of cyanobacteria within a lake. Samples should be taken at multiple spots on a lake which include locations near shore and off shore because surface water temperatures and nutrient concentrations may vary. In China, Lake Taihu was sampled at several locations showing that the shallower sites contain more toxic cyanobacteria than deeper sites (Otten et al., 2012). With multiple 
sites, one will be able to determine the effect of different temperatures and nutrients on cyanobacteria concentrations.

\section{Objective}

The purpose of this project was to examine the relationship between environmental factors and cyanobacteria population density in the local area of McLean County. Lake Bloomington and Evergreen Lake, Illinois, both periodically exceed the EPA standards for nutrients, nitrogen and phosphorus. Lake Bloomington exceeds the EPA limits with high nitrate levels while Lake Evergreen exceeds with high phosphorus

levels. For a cyanobacteria bloom to occur there has to be a low N: P ratio. In addition, I will also examine spatial patterns of cyanobacteria within the lakes. The spatial patterns will involve four sites on each lake. The sites consists of two near shore and two off shores sights. At each site I look at the top, middle, and bottom of the water column. 


\section{Hypothesis}

1. I hypothesized that there would be a higher relative fluorescence unit (RFU) of blue green algae phycocyanin pigment at shallow depths than at deeper depths at each site. In the water column, $1 \%$ sunlight marks the line between the shallow depths and deeper depths. The water above the $1 \%$ mark was shallow and below was the darkness of the deep water. I believe there will be a higher abundance of cyanobacteria above the $1 \%$ mark than below.

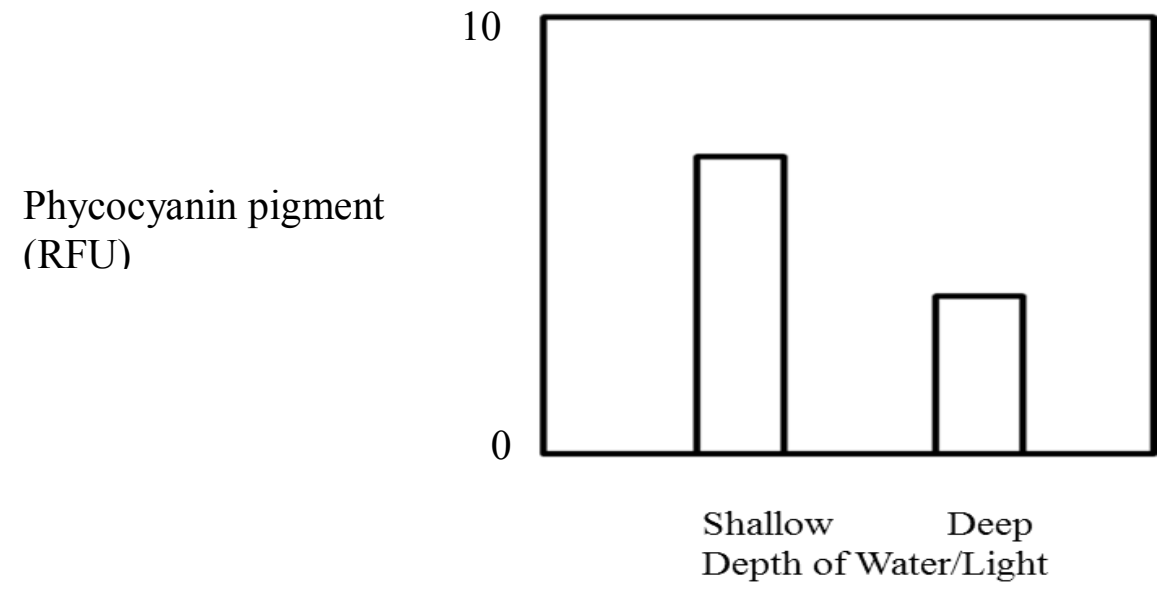

2. Ihypothesize that there would be decrease of blue green algae (BGA) in Lake Bloomington and Evergreen Lake starting in August and ending in October. I believe the controlling factor is temperature (Xu, 2010).

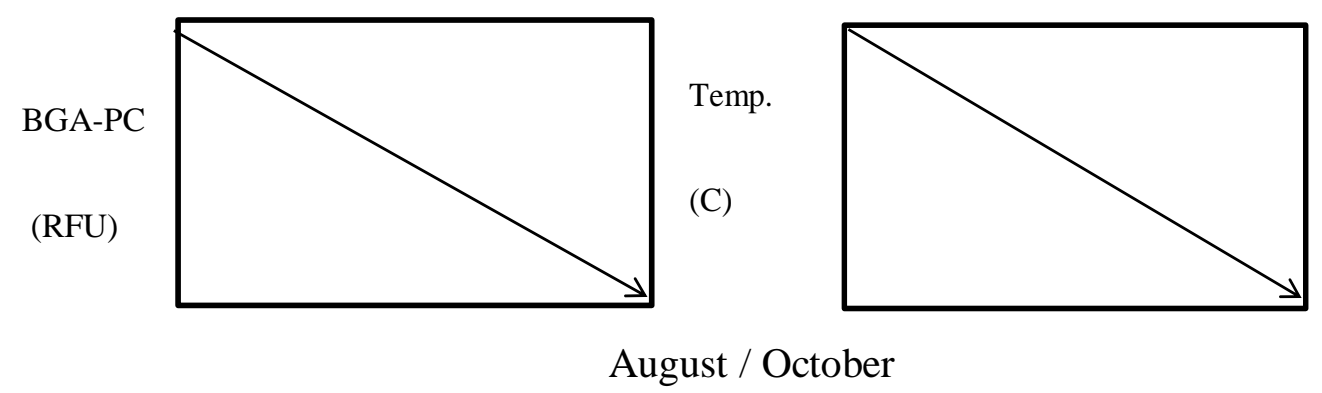


3. I predicted that a low $\mathrm{N}: \mathrm{P}$ ratio in the water would produce a higher concentration of cyanobacteria.

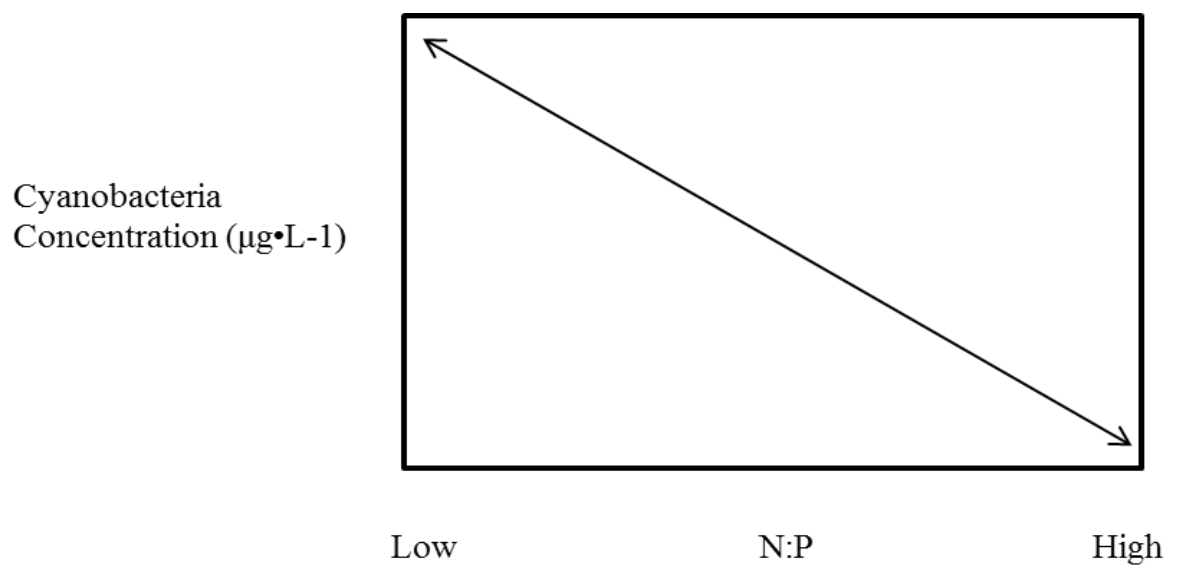

\section{Study Site}

The two study

reservoirs are Evergreen

Lake and Lake

Bloomington located in

central Illinois in McLean

County (Figure 1, Table

2). The watershed for

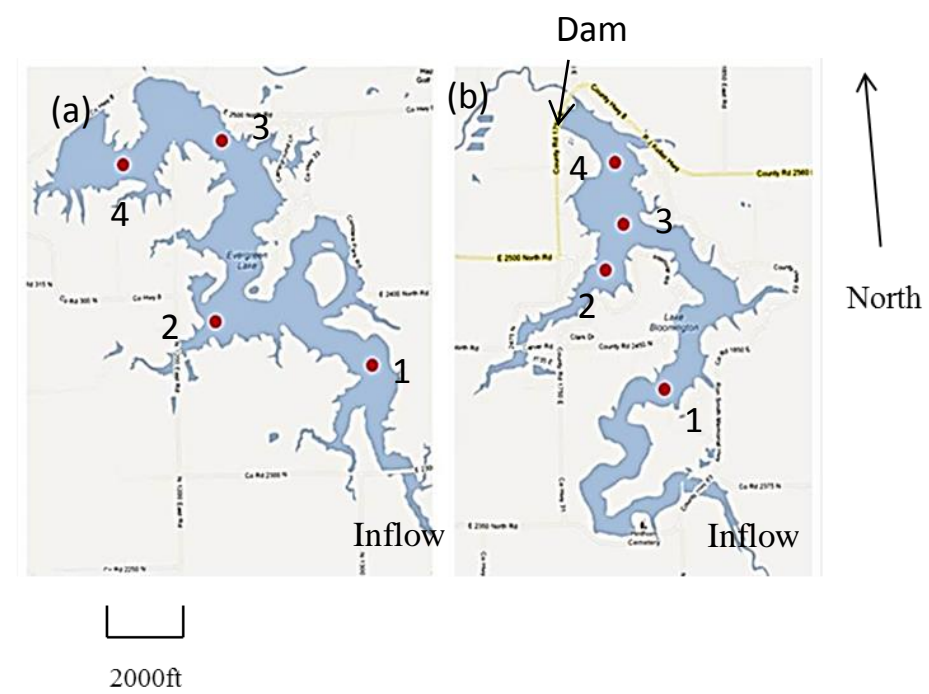

Figure 1: Lake Bloomington and Evergreen Lake (Sites 1-4 Marked as Dots)

\section{Lake Bloomington}

encompasses the upper and lower hydrologic units of Money Creek which is a tributary to the Mackinaw River. There were two reasons that Lake Bloomington was constructed. The first reason was to increase the City of Bloomington water supply. The other reason was for recreation purposes. By raising Lake Bloomington's dam in 1958 raised the water level of the lake. The City of Bloomington increased its water storage capacity by 
56\%. Evergreen Lake was built in 1971 to increase the water supply. This lake was formed by damming Six Mile Creek, which drained into the Mackinaw River (Evergreen Lake Watershed Management, 2008).

Table 2: Watershed Features of Lake Bloomington and Evergreen Lake, McLean County, IL (Lake Bloomington \& Evergreen Lake Watershed Management Plan, 2008).

\begin{tabular}{|c|c|c|}
\hline Features & Lake Bloomington & Evergreen Lake \\
\hline Watershed & 43,000 acres & 25,730 acres \\
\hline Surface area & 572 acres & 900 acres \\
\hline Shoreline & 9.5 miles & 22.5 miles \\
\hline Maximum depth & 35 feet & 53 feet \\
\hline Mean depth & 12.9 feet & 22 feet \\
\hline Storage volume & 6,768 acre - feet & 15,480 acre - feet \\
\hline $\begin{array}{c}\text { N:P ratio } \\
\text { (concentration) }\end{array}$ & $108: 1$ & $5: 1$ \\
\hline
\end{tabular}

In Illinois, 96\% of nitrate load is derived from agriculture (David et al., 1997) (Figure 2) because Lake Bloomington has a higher percentage of the watershed in agriculture than Evergreen Lake does; it is more likely to have higher nutrient concentrations 

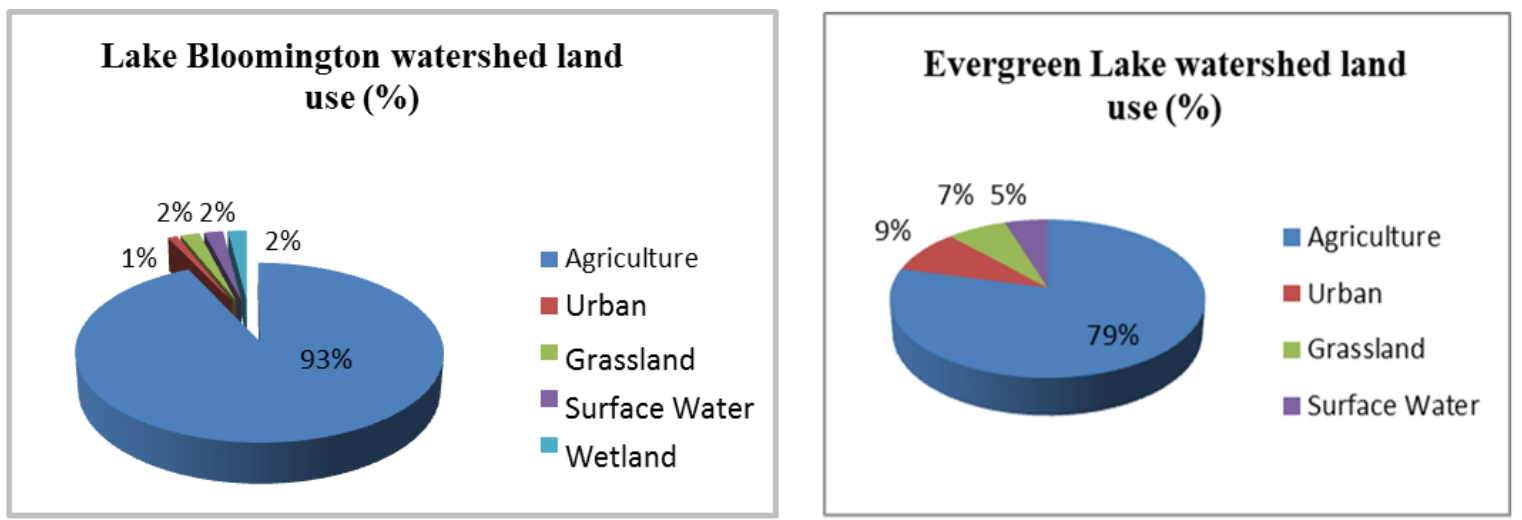

Figure 2: Lake Bloomington and Evergreen Lake Watershed Land Use (\%) (Land Bloomington \& Evergreen Lake Watershed Management Plan, 2008) 


\section{CHAPTER II}

\section{METHODS}

\section{Field Procedure}

Data and samples were collected from four locations in each lake (Figure 1). For each sampling day, data and samples were collected at the same coordinates within range of fifteen to twenty feet (Table 3). It was difficult at times when the sampling day was windy to take data at the same spot. The boat had two anchors to secure the location for the site but the current of the water in the lake would make the boat drift.

The near shore sites were located near the main tributary inputs. The off shore sites were located near the intakes for the City of Bloomington water supply. By gathering information at different places, I had an overview of the distribution of the cyanobacteria count in the two lakes. Sampling was done every other week for three months that started in August and ended in October. The first week in October, data was not collected due to equipment not working. August is typically the hottest part of the summer and water temperatures become cooler leading into the fall. The reason for choosing these months are to have a range of warmer and cooler months. 
Table 3: Samples Sites for Near Shore and Off Shore in Lake Bloomington (LB) and Lake Evergreen (LE), GPS Coordinates and the Average Depth of Each Site.

\begin{tabular}{|l|l|l|l|l|l|l|l|l|}
\hline Lake/ & LB 1 & LB 2 & LB 3 & LB 4 & LE 1 & LE 2 & LE 3 & LE 4 \\
Near/Off- & shore & shore & shore & shore & shore & shore & shore & shore \\
shore & Off- & Near- & Off- & Near- & Near- & Near- & Off- & Off- \\
GPS/ & 88.93 & 88.33 & 88.92 & 88.32 & 89.03 & 89.04 & 89.04 & 89.05 \\
Coordi & $\mathrm{N}$ & $\mathrm{N}$ & $\mathrm{N}$ & $\mathrm{N}$ & $\mathrm{N}$ & $\mathrm{N}$ & $\mathrm{N}$ & $\mathrm{N}$ \\
Nates & 40.66 & 40.64 & 40.65 & 40.63 & 40.63 & 40.63 & 40.64 & 40.64 \\
& $\mathrm{~W}$ & $\mathrm{~W}$ & $\mathrm{~W}$ & $\mathrm{~W}$ & $\mathrm{~W}$ & $\mathrm{~W}$ & $\mathrm{~W}$ & $\mathrm{~W}$ \\
\hline Average & $8.69 \mathrm{~m}$ & $4.1 \mathrm{~m}$ & $6.56 \mathrm{~m}$ & $3.54 \mathrm{~m}$ & $2.66 \mathrm{~m}$ & $4.4 \mathrm{~m}$ & $8.95 \mathrm{~m}$ & $12.8 \mathrm{~m}$ \\
\hline
\end{tabular}

\section{YSI Exo Sonde Probe}

An YSI Exo Sonde probe was used to take profiles of temperature, total algae pigments, conductivity, and dissolved oxygen with depth. The Total Algae sensor on the sonde was used to quantify both chlorophyll a and phycocyanin pigment concentrations $(\mu \mathrm{g} / \mathrm{L})$. Phycocyanin is a secondary pigment in blue-green bacteria that can be used as an estimation of cyanobacteria concentrations (Eriksen, 2008). The walls of the cyanobacteria are too thick for fluorescence techniques of the sensors to accurately detect the chlorophyll a pigment but not the phycocyanin pigment. The phycocyanin pigment is able to be detected through the walls because it absorbs higher wavelengths from the 
sensor than chlorophyll a. Other studies showed a relationship between chlorophyll a, phycocyanin and their extraction differences using the sensors (Zamyadi et al., 2011). The overall phytoplankton group contains predominantly chlorophyll a while cyanobacteria contain both chlorophyll a and phycocyanin, among other pigments.

\section{Secchi Disk}

At each site, I used a secchi disk to estimate the depth of $1 \%$ light transmission to in turn determine the sampling depths between shallow and deep locations. The $1 \%$ sunlight was twice the secchi depth. The $1 \%$ light was the cutoff for phytoplankton and below $1 \%$ is generally considered to be not enough light for phytoplankton to photosynthesize. The Secchi depth is the depth where the secchi disk can no longer be seen in the water column. The secchi disk is twenty centimeters in diameter and white and black for the light to be easily reflected off when lowered in the water. The light that penetrates through the water has a higher reflection off the disk at shallow levels than in deep waters. At deeper waters the light does not make it down in the deep water column for the light to be reflected off from the secchi disk. A secchi disk is lowered in the water column two to four meters (Likens \& Wetzel, 2000). I determined the water column color according to the Illinois Environmental Protection Agency Volunteer Lake Monitoring Program by comparing the color of the water when the disk was at half the secchi depth. The color on the sheet represented if there was an abundance of phytoplankton present in the lake. If the water had a green tint, that represented a high amount of phytoplankton. On the other hand, if the color of the water is brown its more inorganic sediment. 


\section{Grab Sampler and Filtering}

Samples were taken from the surface, $2 \mathrm{x}$ the secchi depth, and deep water (one foot above the bottom) at each location. The total water column depths vary for near shore and offshore deep sites for each lake. The midway sample was taken at twice the secchi depth and the deep sample was taken one foot from the bottom. The midway and deep sample were taken using a grab sampler. Water samples were kept in a cooler until returned to the laboratory where the samples were stored in a refrigerator. In the lab, a known volume of water sample was filtered through a glass microfiber filter (Grade A-E Glass Microfiber Filter Media, $4.7 \mathrm{~cm}$ ) and the filter was kept frozen in a freezer for chlorophyll a analyses. Another subsample was syringe-filtered with- (Pall A/E Glass fiber filters $-(25 \mathrm{~mm})$ and frozen for nitrate, phosphate, and ammonium analyses. Once the field work was completed, I analyzed the frozen subsamples using roughly $10 \mathrm{ml}$ of the filtered water.

\section{Flow Injection Analysis}

The filtered water was run through a Flow Injection Analysis instrument for the chemical portion of the project (Lachat Instruments Inc.). The samples were run separately for each site twice. It was run once for phosphate and ammonium and again for nitrate. For each run, it took roughly forty-five seconds to one minute. Additionally, an unfiltered sample was stored in the refrigerator and analyzed by a FlowCam within one or two days. 


\section{FlowCam}

To examine phytoplankton community composition I used an automated analysis system, a Fluid Imaging Technologies FlowCam. I used one milliliter of water from each grab sample to analyze on a FlowCam. The water samples were filtered using a 100 micron filter before ran though the FlowCam. I looked at two areas for sizes which were 25 microns and 5 microns. The two set sizes were picked to examine larger and small phytoplankton from the lake water. The run on the Flowcam for the first sampling day, I used an objective of 10x but for the other samples I used an objective of $4 \mathrm{x}$ because of instrumentation issues. This is important when looking at the images. The 10x showed a better overall image than the $4 x$.

A FlowCam is an instrument that is capable of imaging and counting cells automatically and analyzes cells or particles at a constant flow rate. By having images, I can see what types of phytoplankton were in the two lakes. The cells and particles were slightly blurry but they showed distinct shapes of the algal cells. I looked at each file and organized the images into similar common particles for the most frequent images. That was for the 25 microns run. For the 5 microns run I used the overall total count since I could not determine similar particles because they were all small and blurry.

For the 25 microns, I organized twelve different like particles into groups called by the letters A through J. All twelve letters were categorized for each lake. Each letter represents different sizes, shapes and/or colors. I chose the top three phytoplankton 
groups for each lake and titled the phytoplankton as being common phytoplankton. The top three for Lake Bloomington were A, D, C and for Lake Evergreen D, C, and I (Table 4). Images in 'D' appear to be diatoms similar to diatoms and images in ' $E$ ' appear to be similar to Ceratium. Ceratium is a genus of dinoflagellate which is blue green algae. The other images are uncertain of what is it so it cannot be suggested a name. 
Table 4: Images from the FlowCam for Lake Bloomington and Lake Evergreen. Images Show Top Three Phytoplankton Groups with the Remaining Common Phytoplankton.

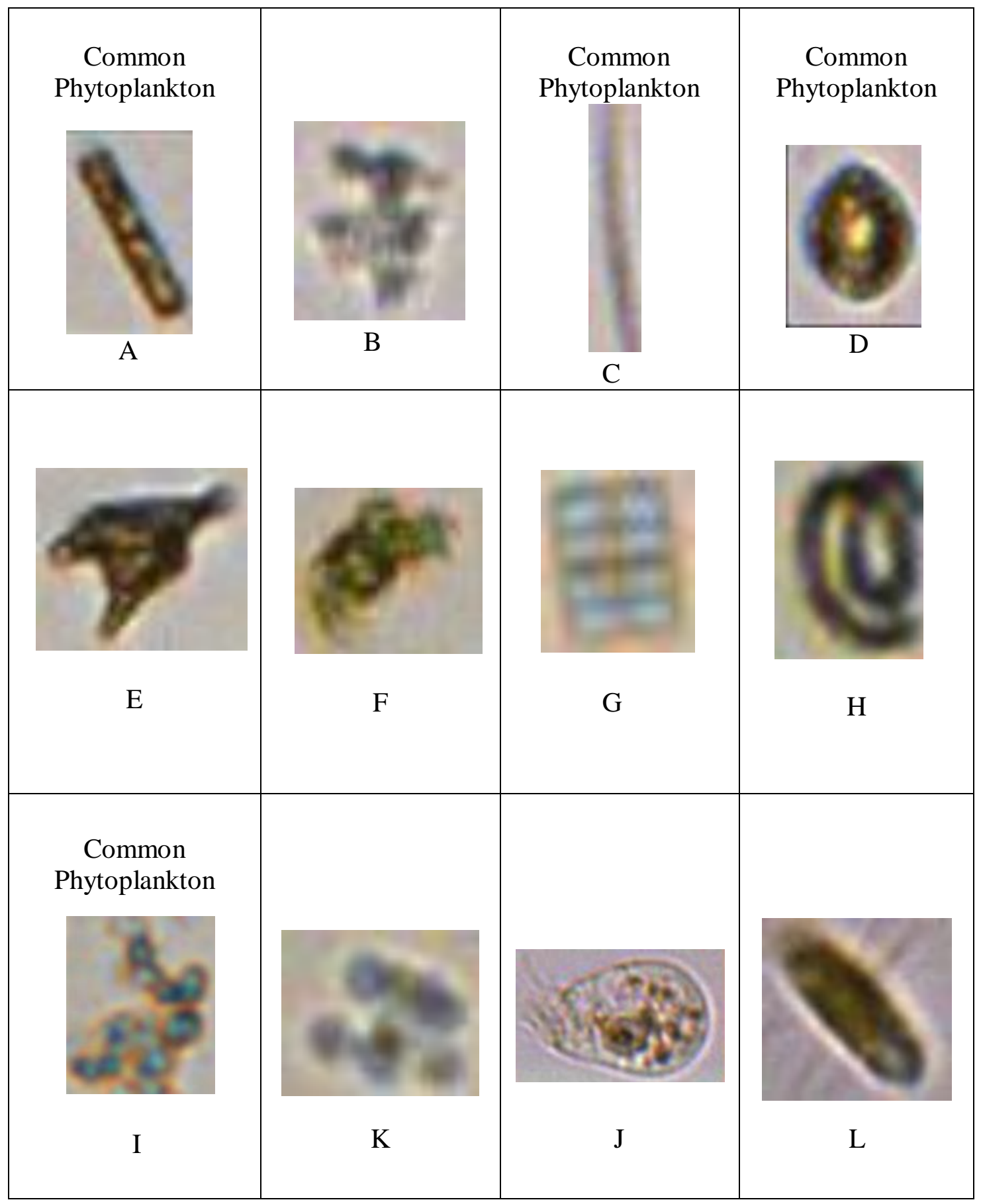


For future FlowCam users the objective is an important factor. The clarity of the images is better using a 10x rather than a 4x. I would also let the sample run for a longer period of time. Therefore, instead of using $1 \mathrm{ml}$ of water to be ran through the FlowCam use 2 or $3 \mathrm{ml}$. That would give an overall higher count of images and possible a higher diverse count of images. 


\section{CHAPTER III}

\section{RESULTS}

\section{Overview}

The study was from August 7, 2013- October 25, 2013. There were measurements collected for temperature, dissolved oxygen, chlorophyll a, BGA-PC, turbidity, nutrients, and also data for a FlowCam. The nutrients data included ammonium, nitrate, and phosphorus. The FowCam showed a count of images displaying phytoplankton.

Table 5: The Mean and Standard Error for Blue Green Algae Phycocyanin, Chlorophyll a, Dissolved Oxygen, Temperature, and Turbidity for Lake Bloomington's and Evergreen Lake's Top, Middle, and Bottom.

\begin{tabular}{|c|c|c|c|c|c|c|c|c|c|c|}
\hline LB & \multicolumn{2}{|c|}{$\begin{array}{c}\text { Temperature } \\
\text { (C) }\end{array}$} & \multicolumn{2}{|c|}{$\mathrm{DO} \% \mathrm{mg} / \mathrm{l}$} & \multicolumn{2}{|c|}{$\begin{array}{c}\text { Chlorophyll a } \\
\text { (ug/l) }\end{array}$} & \multicolumn{2}{|c|}{$\begin{array}{l}\text { BGA- PC } \\
\text { (RFU) }\end{array}$} & \multicolumn{2}{|c|}{$\begin{array}{l}\text { Turbidity } \\
\text { (NTU) }\end{array}$} \\
\hline $\mathrm{T} / \mathrm{M} / \mathrm{B}$ & Mean & $\begin{array}{l}\text { Std. } \\
\text { Err }\end{array}$ & Mean & $\begin{array}{l}\text { Std. } \\
\text { Err }\end{array}$ & Mean & $\begin{array}{l}\text { Std. } \\
\text { Err }\end{array}$ & Mean & $\begin{array}{l}\text { Std. } \\
\text { Err }\end{array}$ & Mean & $\begin{array}{l}\text { Std. } \\
\text { Err }\end{array}$ \\
\hline $\mathrm{T}$ & 22.5 & 1.43 & 125.7 & 5.53 & 5.3 & 0.60 & 3.0 & 0.33 & 12.0 & 2.44 \\
\hline $\mathrm{M}$ & 22.6 & 1.29 & 110.0 & 6.97 & 4.7 & 0.43 & 2.8 & 0.27 & 17.9 & 6.51 \\
\hline B & 22.1 & 1.23 & 59.7 & 7.72 & 3.0 & 0.36 & 2.2 & 0.29 & 50.3 & 12.8 \\
\hline
\end{tabular}

\begin{tabular}{|c|c|c|c|c|c|c|c|c|c|c|}
\hline LE & \multicolumn{2}{|c|}{$\begin{array}{l}\text { Temperature } \\
\text { (C) }\end{array}$} & \multicolumn{2}{|c|}{$\begin{array}{l}\text { DO \% } \\
(\mathrm{mg} / \mathrm{l})\end{array}$} & \multicolumn{2}{|c|}{$\begin{array}{l}\text { Chlorophyll a } \\
\text { (ug/l) }\end{array}$} & \multicolumn{2}{|c|}{$\begin{array}{c}\text { BGA- PC } \\
\text { (RFU) }\end{array}$} & \multicolumn{2}{|c|}{$\begin{array}{l}\text { Turbidity } \\
\text { (NTU) }\end{array}$} \\
\hline $\mathrm{T} / \mathrm{M} / \mathrm{B}$ & Mean & $\begin{array}{l}\text { Std } \\
\text { Err }\end{array}$ & Mean & $\begin{array}{l}\text { Std. } \\
\text { Err }\end{array}$ & Mean & $\begin{array}{l}\text { Std. } \\
\text { Err }\end{array}$ & Mean & $\begin{array}{l}\text { Std. } \\
\text { Err }\end{array}$ & Mean & $\begin{array}{l}\text { Std. } \\
\text { Err }\end{array}$ \\
\hline $\mathrm{T}$ & 22.7 & 1.64 & 135.7 & 8.84 & 2.8 & 0.39 & 2.7 & 0.41 & 21.6 & 6.48 \\
\hline $\mathrm{M}$ & 22.3 & 1.31 & 115.0 & 8.21 & 3.8 & 0.37 & 3.5 & 0.38 & 12.5 & 3.77 \\
\hline B & 17.5 & 1.39 & 50.2 & 8.18 & 2.4 & 0.37 & 2.5 & 0.48 & 22.5 & 3.44 \\
\hline
\end{tabular}




\section{Relationship between BGA -PC \& Temperature}

There was a significant relationship between BGA-PC and temperature for each lake (LB, p 0.0038) (LE, p <.0001). There were two clusters of data, one from approximately between 10 - 15 degrees Celsius and another from 23 - 30 degrees Celsius (Figure 3). The clusters show the collection of BGA - PC from the warmer and colder months. The warmer cluster was the first three sampling events starting in August. The clusters between 10 -15 degrees Celsius were samples of BGA - PC was collected in October, the last collection date (snowing on Evergreen Lake). There is no explanation for why there is only one BGA-PC data point between for Evergreen Lake between 15 to 22 degrees Celsius. 

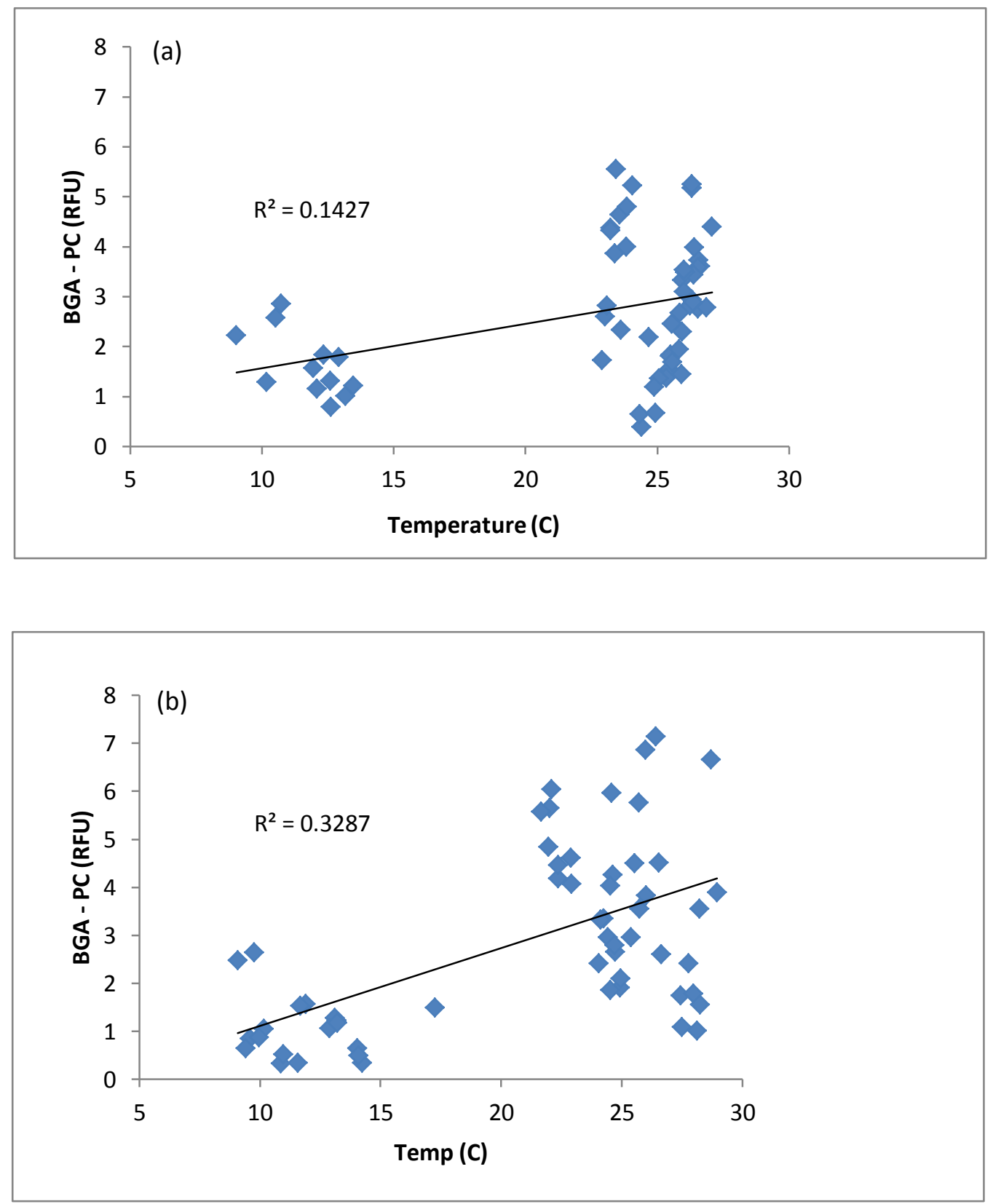

Figure 3: The Relationship between Blue Green Algae - Phycocyanin Concentrations and Water Temperature for Lake Bloomington (a) and Evergreen Lake (b). The Figure Represents Data from Four Sites on Each Lake Collected in August through October for Every other Week. The First Week in October Data was not Collected Due to too not Working Properly. 


\section{Differences among BGA- PC \& Sites}

The difference between sites for BGA - PC was significant in Lake Evergreen (ANOVA, $\mathrm{p}<.0001)$. Location was an important factor. The sites were either near/shore or off/shore. The near/shore sites are shallower than the off/shore sites. Sites 1 and 2 were shallow sites and 3 and 4 were deep sites for Lake Bloomington. Sites 2 and 4 were shallow sites and 1 and 3 were deep sites for Lake Bloomington. There is another factor that increases the amount of BGA -PC. That factor is nutrients of nitrogen and phosphorus. Lake Bloomington BGA-PC was also significantly different among the four sites (p 0.010). Site 4 was significantly different from the other 3 sites. 

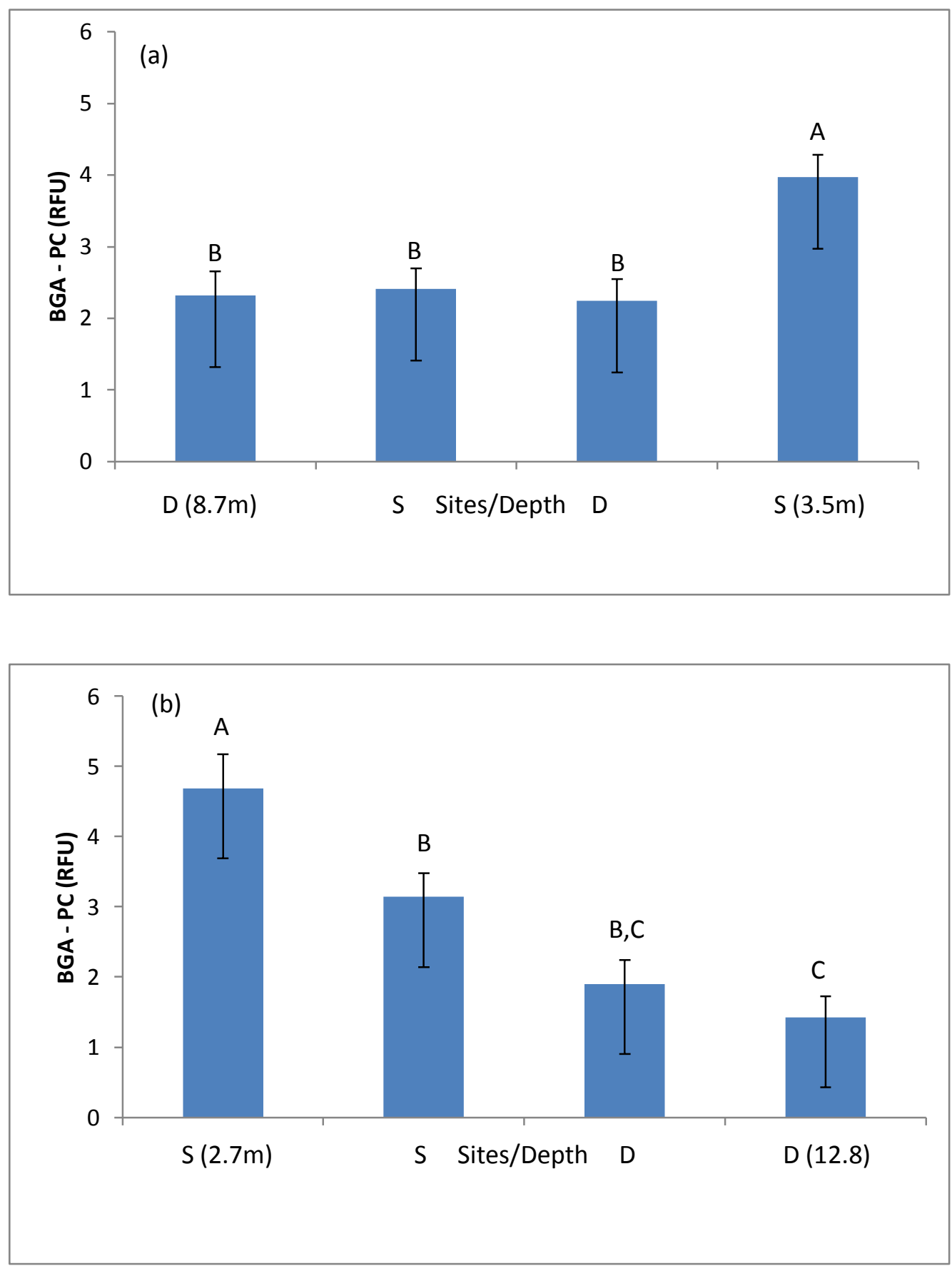

Figure 4: The Differences among Blue Green Algae - Phycocyanin Concentrations at Sampling Sites for Lake Evergreen (a) and Lake Bloomington (b). The Figure Represents Data from Four Sites on Each Lake. Error Bars Represent Standard Error. Letters Represent Results from Tukey HSD. Similar Letters are not Significant having a $\mathrm{P}<0.05$. 


\section{Differences among BGA-PC \& T/M/B}

Both lakes did not show a significant difference between top, middle, bottom of the water column for BGA- PC. The two lakes range roughly between 2 and 4 relative fluorescence unit (RFU) for BGA-PC. In both lakes, the bottom had generally lower BGA-PC concentrations, but this difference was not significant compared to surface and middle concentrations. There was similar data for BGA-PC for the top, middle, and bottom of the water column for both lakes. Overall, Lake Bloomington and Lake Evergreen showed a higher amount at the top and middle than at the bottom of the water column. 

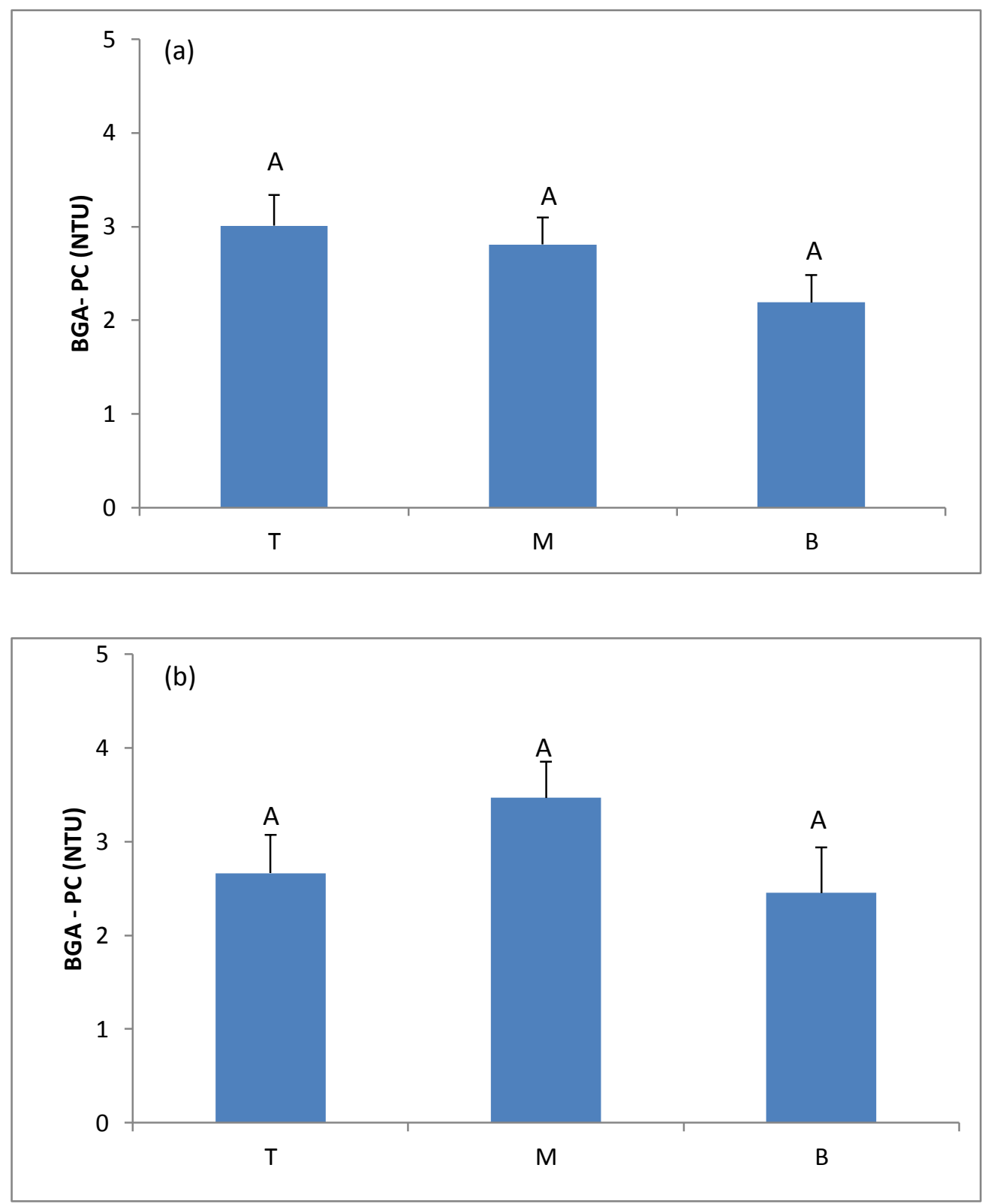

Figure 5: The Differences among Blue Green Algae - Phycocyanin Concentrations for the Top, Middle, Bottom of the Water Column for Lake Bloomington (a) and Evergreen Lake (b). The Figure Represents Data from Four Sites on Each Lake. Error Bars Represent Standard Error. Letters Represent Results from Tukey HSD. Similar Letters are not Significant having a P $<0.05$. 


\section{Differences in Turbidity for T/M/B}

In Evergreen Lake there was a significant difference among turbidity for the top, middle and bottom $(\mathrm{p}<0.0403)$. The least amount of turbidity was at the top and about double at the bottom. The top and middle samples of Lake Bloomington were similar but significantly different from the top. The bottom samples were two to three times higher with a value of roughly 50 (NTU). For Evergreen Lake the values were top, middle bottom were similar overall compared to Lake Bloomington. The top and middle were approximately at 20 (NTU) and the middle was roughly 12 (NTU). 

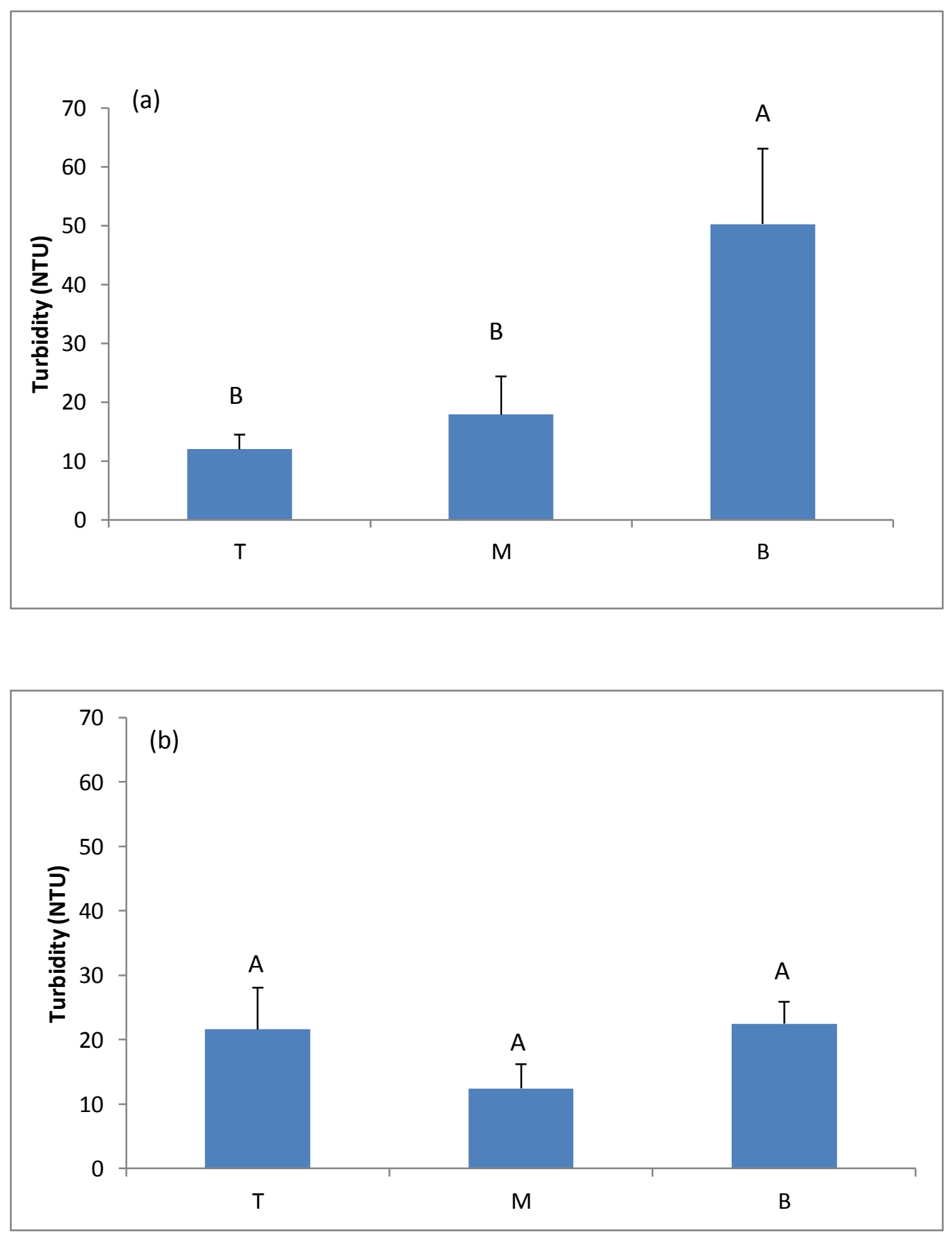

Figure 6: The Differences among Turbidity in the Top, Middle, Bottom of the Water Column for Lake Bloomington (a) and Evergreen Lake (b). The Figure Represents Data from Four Sites on Each Lake. ErrorBars Represent Standard Error. Letters Represent Results from Tukey HSD. Similar Letters are not Significant having a $\mathrm{P}<0.05$. 


\section{Relationship between BGA- PC \& $\log$ N: P ratio}

Both Lake Bloomington and Evergreen Lake did not show a significant relationship between BGA-PC and N:P ratio. Lake Bloomington and Evergreen have similar ranges of $\mathrm{N}: \mathrm{P}$ ratios, although Lake Bloomington has a slightly higher ratio than Lake Bloomington. However, Evergreen Lake has a higher BGA-PC relationship to nutrients of nitrogen and phosphors then does Lake Bloomington. Evergreen Lake is also spread out from a $\log \mathrm{N}: \mathrm{P}$ ratio of 3 to nearly 8 while Lake Bloomington showed a gap of BGA-PC from four an half to five an half. Overall, both lakes showed a low N:P to a high concentration of BGA-PC. 

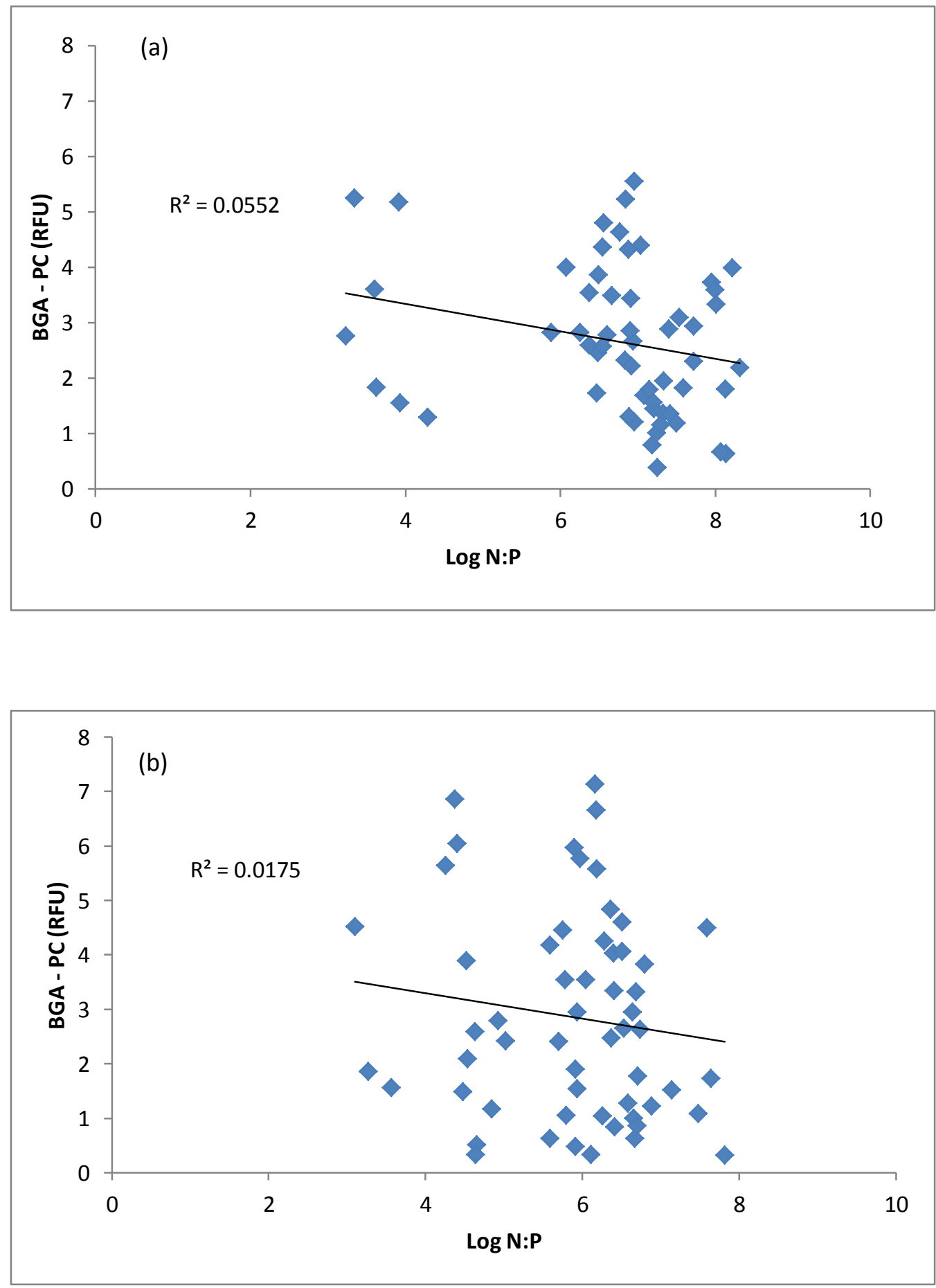

Figure 7: The Relationship between Blue Green Algae - Phycocyanin Concentrations and Log N: P Ratio for Lake Bloomington (a) and Evergreen Lake (b). The Figure Represents Data from Four Sites on Each. 


\section{FlowCam Results}

Lake Evergreen showed fewer phytoplankton overall than Lake Bloomington.

From August to October, the population of phytoplankton did not rapidly decrease until October for Lake Bloomington. The majority of the highest count of phytoplankton was the fifth sampling day on September $23^{\text {rd }}$. The first sampling for Lake Evergreen showed the highest population of phytoplankton than the other four sampling days. The remaining sampling days were below 30 for a phytoplankton count. Overall, there was one count on the first sampling day found on site 3 that was high. It had a count that was roughly 375 particles. 

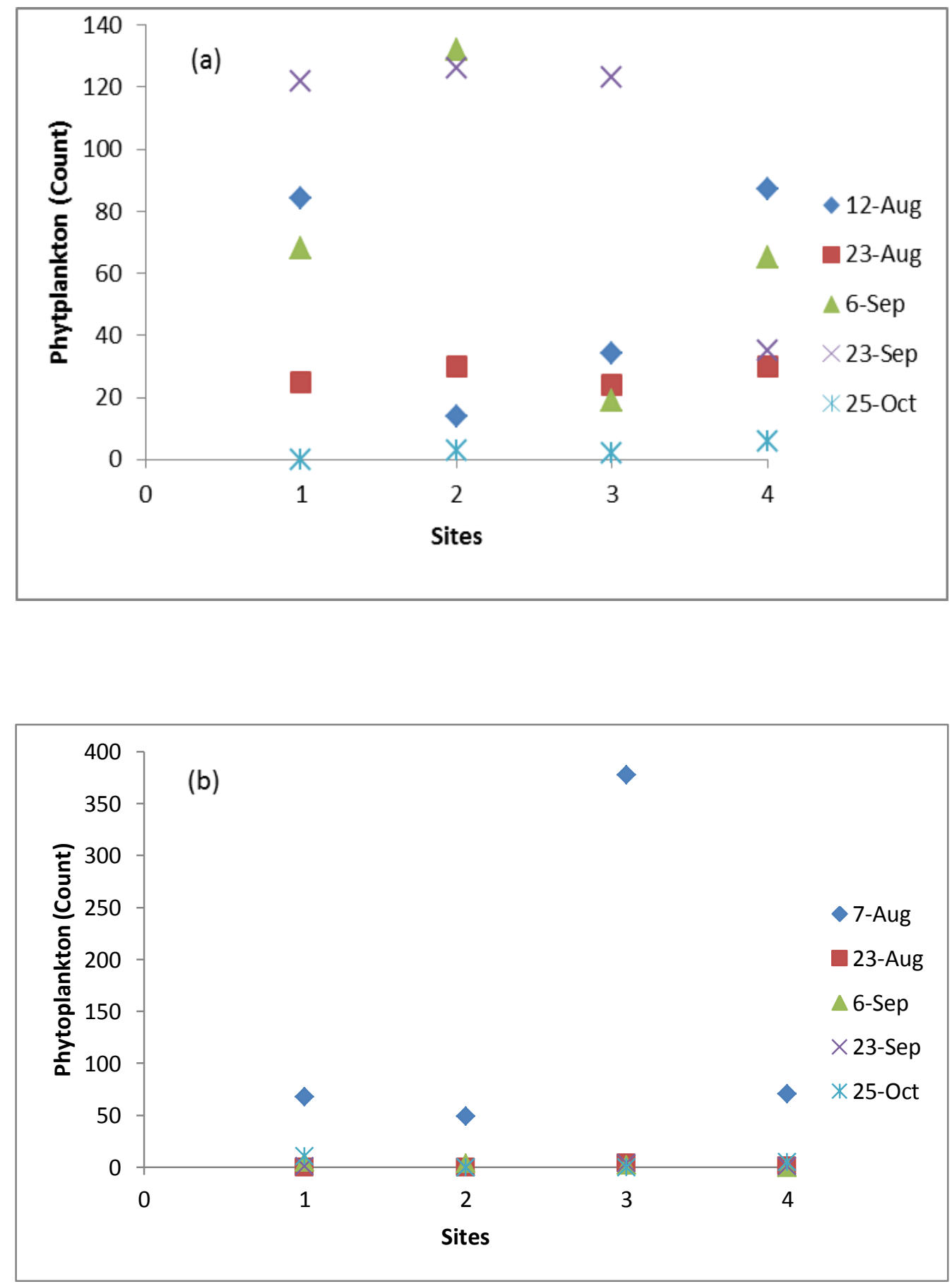

Figure 8: The Total Count at 25 microns for Each Site for Lake Bloomington (a) and Evergreen Lake (b). This Figure Represents Data for All Five Sampling Days Starting in August and Ending in October. 


\section{Depths \& Sites}

All four sites of Lake Bloomington had a higher count of phytoplankton than

Evergreen Lake except for one site. The site at Evergreen Lake that was higher than Lake Bloomington was at a depth of eight to eight and half deep. That count was roughly 400 phytoplankton. The remaining sites had a count of 100 phytoplankton or below. Lake Evergreen had the deepest depth having a low count of roughly 75 phytoplankton. For Lake Bloomington all sites were roughly between a count of 175 and 325 particles. The highest count for Lake Bloomington is at a depth of three to four meters. Overall there was no pattern of higher counts at a shallow depth and lower count at a deeper depth.

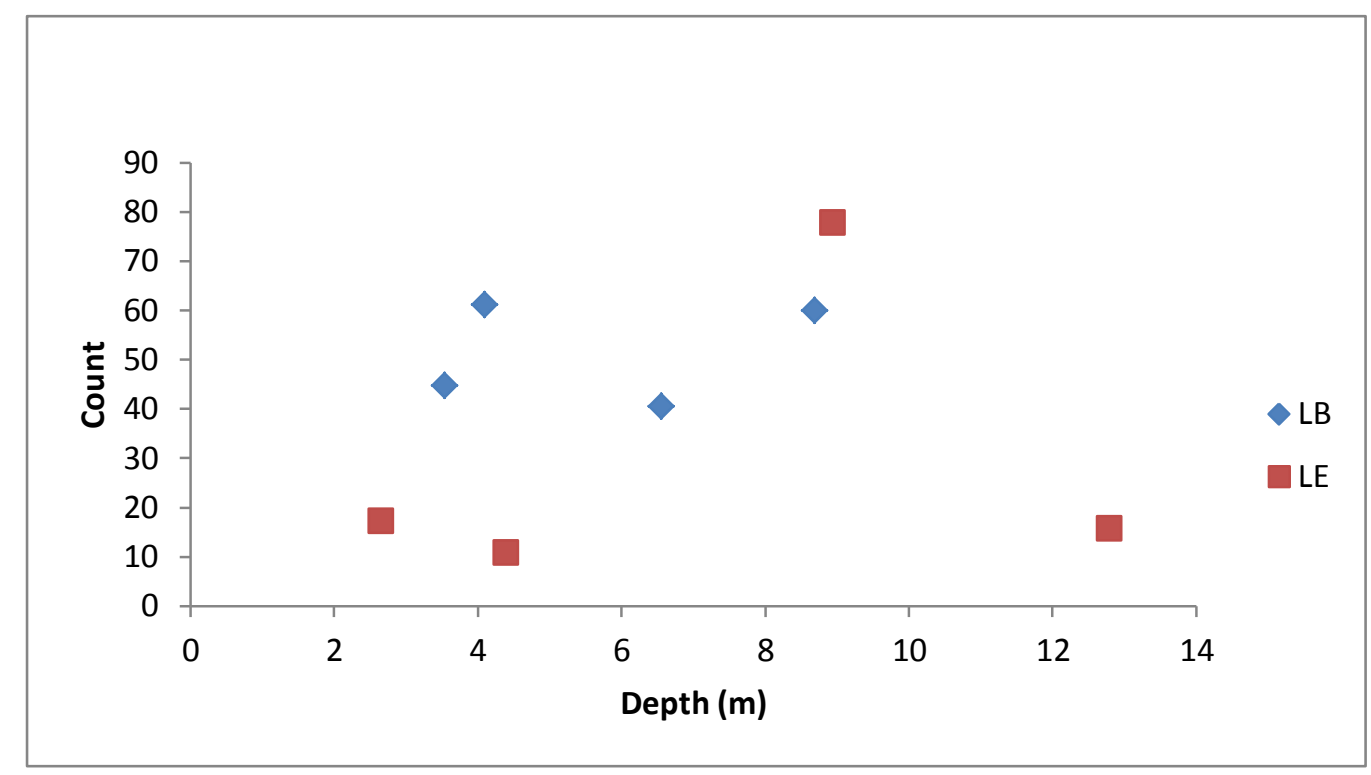

Figure 9: The Relationship between Total Water Depths at of Each Site and the Total Count of Images that were Taken on the FlowCam for Lake Bloomington and Evergreen Lake. The Data Represents Averages for All Five Sampling Days Starting in August and Ending in October.

\section{Top Three Common Phytoplankton Groups}

The common phytoplankton group showed a high of roughly 120 counts for Lake Bloomington and Lake Evergreen with a high of 300. For Evergreen Lake the highest 
sampling day was the first sampling day which was August $7^{\text {th }}$. A $10 \mathrm{x}$ was used on the FlowCam instead of a 4x. That should not be the explanation for why the count is higher than the remaining sampling days. The three most common letters for the highest algal cell count was D with the highest then $\mathrm{C}$ and I. Lake Bloomington shows a variety of common phytoplankton except for the last sampling when it was cold have the lowest count. For Lake Bloomington, A and C had the highest population on September $23^{\text {rd }}$. B shows to be the highest on September 6. There are two graphs for Lake Evergreen representing the first sampling day for graph (b) and the remaining days on graph (c). The two graphs were created for a better scale representation.

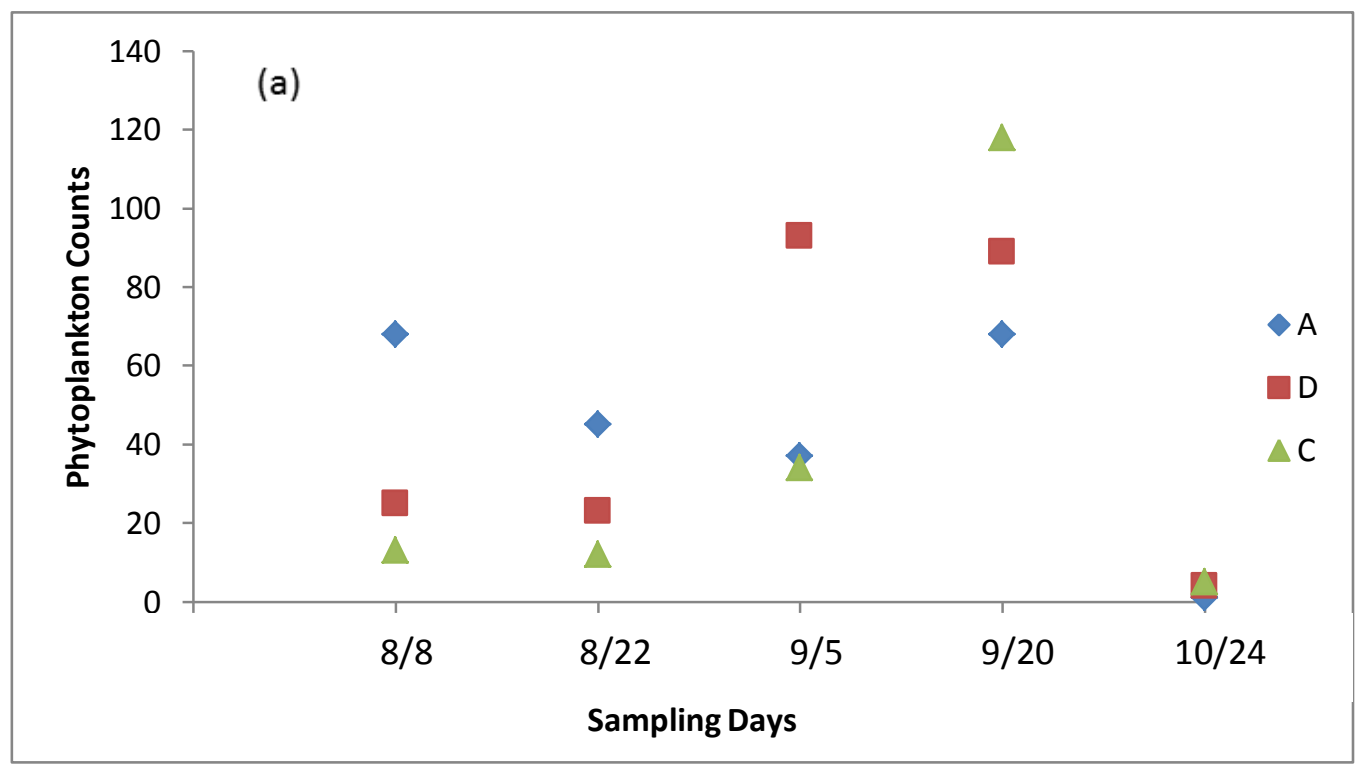



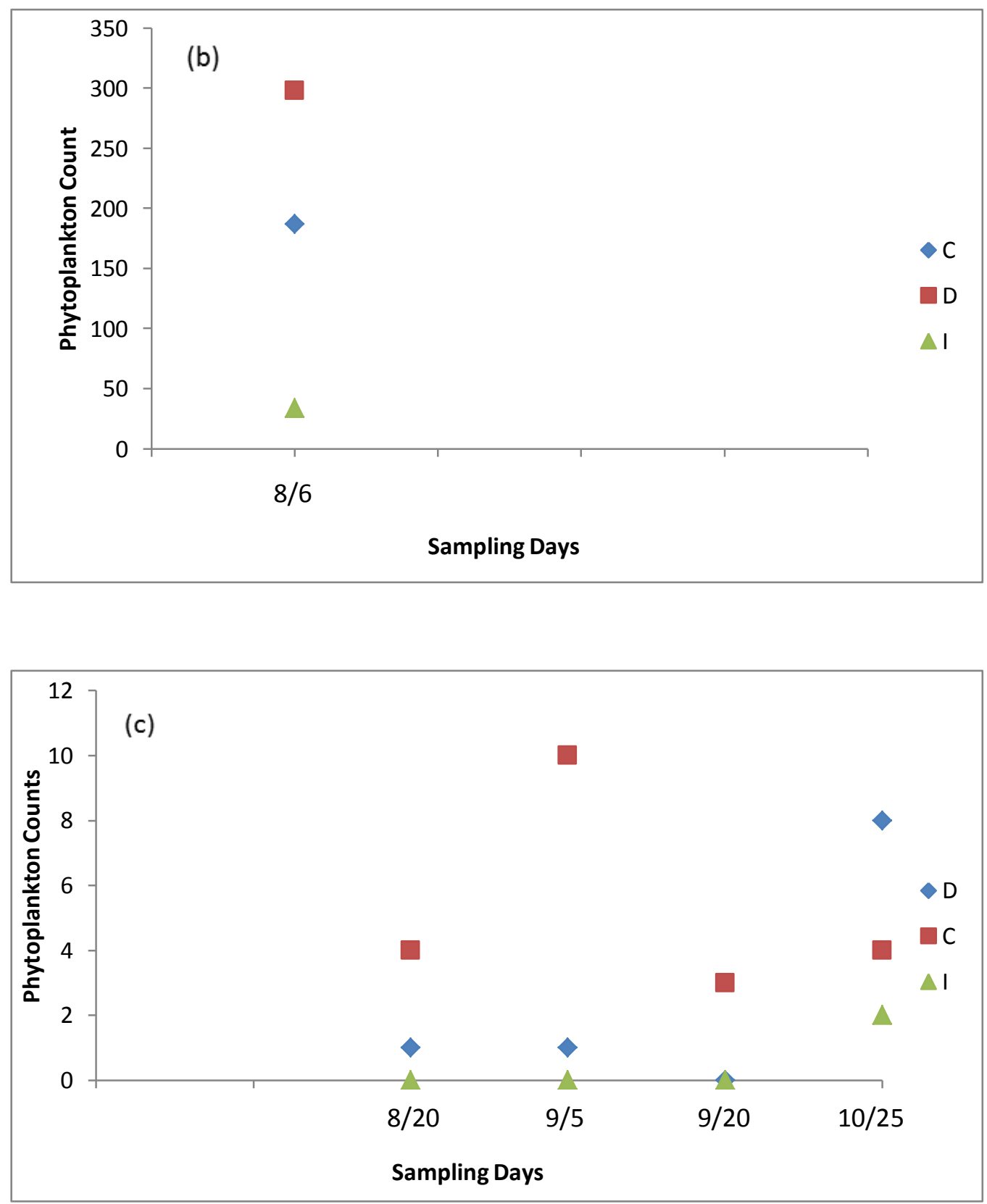

Figure 10: The Two Graphs Represents the Total Count 25Microns for the Top 3 Groups between All Five Sampling Days for Lake Bloomington (a) and Evergreen Lake (b) and (c). 


\section{FlowCam (5 microns)}

For both lakes there was more phytoplankton that range in the size of 5 microns than in 25 micron. Comparing the 25 and 5 microns over the five sampling events shows the least amount of phytoplankton on October $25^{\text {th }}$. Compared to the 25 microns, the counts of phytoplankton increase by hundreds and some thousands. Lake Bloomington overall showed more phytoplankton in 5 microns than does Lake Evergreen. The majority of the population of the phytoplankton for each lake was found in the top and middle samples than the bottom sample of the water column. The highest count of phytoplankton was found at site 1 on Lake Bloomington in a middle sample. Site 1 was an off-shore site. It was next to the water treatment plant and roughly eight and half to nine meters deep. The amount was 18,555 counts. That occurred on September $23^{\text {rd }}$. It was a large amount with only being one milliliter of water ran through the FlowCam. For Lake Evergreen, the highest count was much lower being a middle sample at a shallow site. This site was roughly 2 and half to 3 meters deep. The amount of phytoplankton was 484 counts. That occurred on the last sampling day. 


\section{CHAPTER IV}

\section{DISCUSSION}

\section{Influence of Water Temperature \& Depth on BGA-PC}

The water temperature and depth were related August through October and this appeared to influence BGA-PC and chlorophyll. Overall, throughout those months there was more BGA-PC and chlorophyll a found at shallow and middle sections of the water column then at the bottom. One study reports there is a long-term dominance of filamentous species at shallow depths (Dokuli at el., 2000). Another recent study has shown that Microcystis, toxic cyanobacteria, quickly grow in the spring then dominated in the summer (Xu et al., 2010). The reasoning is due from sunlight warming the water temperature. The sunlight hits the surface water penetrating the surface into the water column. The middle section is at the $1 \%$ sunlight in the water column before darkness in the water. Having no sunlight below the $1 \%$ will cause less of BGA-PC. The bottom samples collected had BGA-PC data due to the warming temperatures above in the water column.

The top and middle section of water had a higher overall count of phytoplankton then the bottom samples collected. Focusing on the top and middle section of the water column, Lake Bloomington had an over higher count of phytoplankton at the surface while Evergreen Lake had more at the middle section of the water column. Since each 
lake was sampled the same there is not an explanation for top and middle overall phytoplankton count. For the future, if samples were collected directly in the middle of the water column. Evergreen Lake may have lower amounts of phytoplankton then Lake Evergreen. That is explained by depth. The average depth at Evergreen Lake is deeper than Lake Bloomington. With that, at deeper depths the sunlight has farther to penetrate in the water column not being able to warm the temperatures.

This relationship between water temperature and cyanobacteria abundance is consistent with my predictions and with what other studies have found. A study of four lakes in the County of Athabasca of central Alberta showed that 10 cyanobacteria species were highly populated in the months of June, July and August. The surface water temperature was warming in June having a maximum temperature of 22 degrees Celsius in July and August (Zhang et al., 1996). The same study explained that cyanobacteria growth rate is higher during the summer than the colder months. For example, a species of cyanobacteria, Ceriodaphnia, were more inhibited at 27-30 degrees Celsius than 25 degrees Celsius. Therefore, the warmer the cyanobacteria are exposed to the more abundant of them there will be. Also a toxic cyanobacterium, Microcystis aeruginosa, is more likely to evolve in water temperatures between 19-24 degrees Celsius than 12-14 degrees Celsius (Claska et al., 1998).

\section{Spatial Patterns in Nutrients \& BGA-PC}

The four different sites on each lake shared a relationship with depth and nutrients. The nutrients implied the increase of BGA-PC at the near shore sites. The near 
shore sites were closer to the intakes of each lake. The stream may bring in nutrients reaching the near shore sites first before the off shore deep sites. With addition to the depth being a factor, the nutrients being washed in increased the BGA-PC concentration.

The depth may be the best factor while looking at BGA-PC instead of nutrients. The percentage of watershed for agriculture for Lake Bloomington is higher than Evergreen Lake. The percentage is higher but slightly a lower amount of BGA-PC concentration than Evergreen Lake. In the end, assuming with having a larger watershed percentage of agriculture the BGA-PC would also be high. The differences between the watersheds were $93 \%$ and $79 \%$. Other factors have to be accounted for such as how much nutrients were added in within each percentage.

Nutrients not only affect phytoplankton on Lake Bloomington and Evergreen Lake but other studies. A study was done in Steele Lake, Canada examining nutrients levels. This study was looking at the normal and high amounts of nutrients added in the lake and how it would affect the cyanobacteria at shallow waters (2m) and deep wasters (5m) Overall, for the four types of cyanobacteria that were used, the shallow water showed more cyanobacteria than the deep water (Ghadouani et al, 2003). This is relevant to the Lake Bloomington and Evergreen study showing at shallower water near the surface of the water column there is a higher amount of cyanobacteria. Both studies agree same with the deep water in the water column having fewer cyanobacteria. Also, three out of the four cyanobacteria that were used, the high amounts of nutrients was more affected to the cyanobacteria than the normal amount of treatment used (Ghadouani et al., 2003). 
Overall, Lake Bloomington and Lake Evergreen N:P ratios were similar in range for all sites including top, middle and bottom. The relationship between the BGA-PC and $\mathrm{N}: \mathrm{P}$ ratio was slightly higher at Lake Evergreen than at Lake Bloomington. With having a higher $\mathrm{N}: \mathrm{P}$ than a low $\mathrm{N}: \mathrm{P}$ will cause less of a BGA-PC growth. Nutrients did not play a big factor in the growth of cyanobacteria concentration on the two lakes but it does contribute according to the Canada study.

\section{Turbidity \& BGA-PC}

Next factor that is related to the BGA-PC concentration is turbidity. Turbidity is the stirred up sediment and suspended particles that creates a cloudy haziness in the water. The water can be crystal clear with low turbidity or the water can be practically mud having a high turbidity value. In reality, the turbidity should be higher towards the bottom of the water column where the sediment falls and settles out. But, turbidity can also be high at the surface. Turbidity can not only be defined as an inorganic rock fragment but organic material such as phytoplankton. The mucky green substance floating at the surface is cyanobacteria which entails having high turbidity. Lake Bloomington or Lake Evergreen did not have high amounts of turbidity where cyanobacteria were visible at the surface.

Lake Bloomington and Evergreen Lake ranged in turbidity at low of 10 and a high of 50 NTU's. Both lakes color distributions were a green color the beginning of the data collections and over the course of the three-month research period became less green and browner. Another term for cyanobacteria is blue green bacteria indicating the green was 
cyanobacteria from the other remaining phytoplankton. It may not be only cyanobacteria causing the water to be green but a high majority. That reflects the cyanobacteria biomass was not at a high level as in the beginning of August. Throughout the sampling period, green mats of algae were not found at the four site locations on each lake. That indicates there was not a high amount of cyanobacteria in the middle of the lake. The only green mats of algae were spotted around shoreline of the lakes suggesting that is the highest area of nutrients concentration that has washed into the lakes which triggered the growth of cyanobacteria.

\section{Phytoplankton Counts}

The overall phytoplankton counts were greater at Lake Bloomington than Evergreen Lake. By looking at both the graphs the temperature was not the main factor. Same with the sunlight, it was not relevant to a high amount of phytoplankton. The counts of phytoplankton were high in the deep waters of the water column. The other factor that plays a role in the population growth of phytoplankton is nutrients of nitrogen and phosphorus. Lake Bloomington did show a lower N:P ratio than Evergreen lake (Figure (BGA vs Log N:P)). With having a low N:P ratio increases the phytoplankton count. From looking at the factors and comparing the counts to runs by the Bloomington treatment plant lab technician the lakes showed Bloomington was higher in phytoplankton.

Both lakes did not really show a pattern from sampling day one when it was warm to the last sampling day when it was the coldest. Besides the last day being 36 degrees 
Fahrenheit on Lake Bloomington and 38 degrees on Evergreen Lake. Temperatures being that low produced a very low amount of a phytoplankton count for both lakes. Lake Bloomington showed a wide range of amounts of counts from sampling day one to sampling day four. The temperatures for both those sampling day runs were roughly 69 to 70 degrees Fahrenheit. Then for Evergreen Lake all of the counts were low except for one for site 3. This was on the first sampling day, August $7^{\text {th }}$. This did not have an explanation for why it is much higher than the remaining sampling day sites. 


\section{CHAPTER V}

\section{CONCLUSION}

The main factor associated with increased growth of cyanobacteria was temperature. Additionally, the direct sunlight and nutrients played an important role. From August through October, the cyanobacteria concentrations decreased with temperature. The sampling day in October revealed a drastic decline of cyanobacteria compared to other days out on the lakes. Next, the other factor is sunlight along with temperature affecting the surface more than the bottom. Overall, there was a higher concentration at the top than at the bottom. There were some samples in late October that did show the bottom had a higher concentration then the top. The water was turning over, being warmer at the bottom than the, top during the colder months, suggesting that temperature, rather than sunlight was the main factor affecting growth. Lastly the lakes had an overall low to $\mathrm{N}: \mathrm{P}$ ratio, when the concentration of BGA-PC was high.

Overall, there was no difference in cyanobacteria concentrations between the lakes, and the population levels of cyanobacteria were not extremely high in either lake. The highest cyanobacteria concentrations in each lake were near the main tributary inlets. The color of the lakes was green when the temperatures were warmer but green mats were not visible except around the shorelines. Also, the lakes did not exceed the EPA 
nutrients level that might have caused occurrence of high concentration, of cyanobacteria of which some may have been toxic.

For future work there are multiple questions that could be resolved. For example, how much higher are the cyanobacteria populations at the shallow and deep sites before, during and after a rain event? Another question, is how much more abundant are the cyanobacteria during the colder months (November, December, January, and February) at the bottom of the lake rather than at the surface? To address these questions, an Exo sonde probe could be placed on each lake. Based on the results of this project, the deeps sites would be better to use overall because at the bottom it is completely dark with no light. At some of the shallow sites the light penetrates close to the bottom, warming the bottom of the water column. 


\section{REFERENCES}

Carmichael, W.W. (1992) Cyanobacteria secondary metabolites - the cyan toxins, Vol 72, pp. 445-459.

Cheung, Melissa. (2013) "Toxin- producing Cyanobacteria in Freshwater: A Review of the Problems, Impact on Drinking Water Safety, and Efforts for Protecting Public Health.” Journal of Microbiology, Vol. 51, No. 1, pp. 1-10.

Backer, Lorraine C. (2002) "Cyanobacterial Harmful Algal Blooms (CyanoHAbs):

Developing a Public Health Response.” Lake and Reservoir Management, Vol 18, pp. $20-31$

Backer. (2009) "Recreational exposure to microcystins during algal blooms in two California lakes.” Evergreen Lake Watershed Planning Committee, Evergreen Lake Watershed Plan, 2008 Bloomington, IL.

Dokuli, Martin T. (2000) "Cyanobacterial dominance in lakes." Hydrobiologia, Vol. 438, pp. 1-12.

Ghadouani, Anas. (2003) Effects of experimentally induced cyanobacterial blooms on crustacean zooplankton communities, Vol. 48, pp. 363-381.

Eriksen, NT. (2008) Production of phycocyanin - a pigment with applications in biology, biotechnology, foods and medicine, Vol. 1, pp. 1-14.

Harris, TD. (2014) "Experimental manipulation of TN:TP ratios suppress cyanobacterial biovolume and microcystin concentration in large-scale in situ mesocosms." Lake and Reservoir Management, Vol. 30, pp. 72-83.

Horst, GP. (2014) "Nitrogen availability increases the toxin quota of a harmful cyanobacterium, Microcystis aeruginosa." Water Research, Vol 54, pp. 188-198.

Hudnell, Kenneth H. (2009) "Freshwater harmful algal bloom (FHAB) suppression with solar powered circulation (SPC).” Harmful Algae, Vol 9, pp. 208-217.

Lake Bloomington Watershed Plan, Lake Bloomington Watershed Planning Committee, June 22, 2008. Bloomington, IL. 
Lathrop. "Phosphorus loading reductions needed to control blue-green algal blooms in Lake Mendota. (1998) Vol. 55, pg. 1169-1178.

Levinson DH, Waple AM (2004) State of climate in 2003. Bulletin of the American Meteorological Society, Vol. 85, pg. S1-S72.

Likens \& Wetzel, 2000. Limnological Analyses, W.B Saunders. New York.

Orihel, Diane M. (2012) High microcystin concentrations occur only at low nitrogen- tophosphorus ratios in nutrient -rich Canadian lakes, Vol. 69, pp. 1457-1462.

Otten. (2012) "Spatiotemporal Patterns and Ecophysiology of Toxigenic Microcystis Blooms in Lake Taihu, China: Implications for Water Quality Management." Enivronmental Science \& Technology.

Packer \& Glazer (1988) Cyanobacteria secondary metabolites - the cyanotoxins, Vol. 72, pp. $445-459$.

Sedmak, Bojan \& Kosi, Gorazd. (1998) "The role of microcystins in heavy cyanobacterial bloom formation.” pp. 691-708.

Rolland. (2013) "Extreme variability of cyanobacterail blooms in an urban drinking water supply." Journal of plankton research, Vol. 35, pp. 744-758.

Teixera. (2013) "Toxin- producing Cyanobacteria in Freshwater: A Review of the Problems, Impact on Drinking Water Safety, and Efforts for Protecting Public Health.” Journal of Microbiology Vol. 51, No. 1, pp. 1-10.

Xu. (2010) "Dynamics of the water bloom-forming Microcystis and its relationship with physiochemica factors in Lake Xuanwu (China) Vol. 17, pg 1581-1590.

Zamyadi. (2012) "Monitoring of potentially toxic cyanobacteria using an online muliprobe in drinking water sources." Journal of environmental monitoring (2012) Vol. 14, pp 579- 588. 